Supplemental Information for

\title{
Proton Coupled Electron Transfer and Tyrosine D of Photosystem II
}

\author{
David L. Jenson, Amaris Evans and Bridgette A. Barry \\ Department of Chemistry and Biochemistry and the Petit Institute for Bioengineering and \\ Bioscience, Georgia Institute of Technology, Atlanta, GA 30332
}


Table S1. Summaries of the minority (fast) phase amplitudes, rate constants, and kinetic isotope effects, as well as the amplitude of the non-decaying phase $\left(\mathrm{C}_{0}\right)$, for $\mathrm{YD}^{\bullet}$ decay, as assessed by EPR spectroscopy ${ }^{\mathrm{a}}$

\begin{tabular}{|c|c|c|c|c|c|}
\hline $\mathrm{pL}$ & Buffer & $\begin{array}{l}\text { Fast Phase } \\
\text { Rate }\left(10^{-3} \mathrm{~s}^{-1}\right)^{\mathrm{b}}\end{array}$ & $\begin{array}{l}\text { Fast Phase } \\
\text { Amplitude } \\
(\%)^{\mathrm{b}}\end{array}$ & $\begin{array}{l}\text { Non-Decaying } \\
\text { Component } \\
(\%)^{\mathrm{b}} \\
\end{array}$ & $\mathrm{KIE}^{\mathrm{c}}$ \\
\hline \multirow[t]{2}{*}{5.5} & $\mathrm{H}_{2} \mathrm{O} / \mathrm{MES}$ & $8.72 \pm 0.70$ & $8 \pm 3$ & $\mathrm{ND}$ & \multirow[t]{2}{*}{$1.6 \pm 0.2$} \\
\hline & $\mathrm{D}_{2} \mathrm{O} / \mathrm{MES}$ & $5.33 \pm 0.51$ & $10 \pm 2$ & $\mathrm{ND}$ & \\
\hline \multirow[t]{2}{*}{6.0} & $\mathrm{H}_{2} \mathrm{O} / \mathrm{MES}$ & $6.63 \pm 1.20$ & $8 \pm 1$ & ND & \multirow[t]{2}{*}{$1.2 \pm 0.2$} \\
\hline & $\mathrm{D}_{2} \mathrm{O} / \mathrm{MES}$ & $5.42 \pm 0.22$ & $6 \pm 1$ & ND & \\
\hline \multirow[t]{2}{*}{6.5} & $\mathrm{H}_{2} \mathrm{O} / \mathrm{MES}$ & $4.38 \pm 0.75$ & $6 \pm 1$ & $\mathrm{ND}$ & \multirow[t]{2}{*}{$0.8 \pm 0.2$} \\
\hline & $\mathrm{D}_{2} \mathrm{O} / \mathrm{MES}$ & $5.49 \pm 1.40$ & $5 \pm 1$ & ND & \\
\hline \multirow[t]{2}{*}{7.0} & $\mathrm{H}_{2} \mathrm{O} / \mathrm{MES}$ & $4.84 \pm 0.70$ & $5 \pm 1$ & ND & \multirow[t]{2}{*}{$1.4 \pm 0.5$} \\
\hline & $\mathrm{D}_{2} \mathrm{O} / \mathrm{MES}$ & $3.55 \pm 1.09$ & $5 \pm 2$ & $\mathrm{ND}$ & \\
\hline \multirow[t]{2}{*}{7.0} & $\mathrm{H}_{2} \mathrm{O} / \mathrm{HEPES}$ & $4.93 \pm 0.43$ & $5 \pm 1$ & $\mathrm{ND}$ & \multirow[t]{2}{*}{$1.1 \pm 0.2$} \\
\hline & $\mathrm{D}_{2} \mathrm{O} / \mathrm{HEPES}$ & $4.50 \pm 0.55$ & $4 \pm 1$ & $\mathrm{ND}$ & \\
\hline \multirow[t]{2}{*}{7.5} & $\mathrm{H}_{2} \mathrm{O} / \mathrm{HEPES}$ & $5.38 \pm 1.29$ & $4 \pm 1$ & ND & \multirow[t]{2}{*}{$0.9 \pm 0.6$} \\
\hline & $\mathrm{D}_{2} \mathrm{O} / \mathrm{HEPES}$ & $5.96 \pm 3.40$ & $3 \pm 1$ & $\mathrm{ND}$ & \\
\hline \multirow[t]{2}{*}{8.0} & $\mathrm{H}_{2} \mathrm{O} / \mathrm{HEPES}$ & $4.49 \pm 0.92$ & $5 \pm 1$ & ND & \multirow[t]{2}{*}{$1.0 \pm 0.4$} \\
\hline & $\mathrm{D}_{2} \mathrm{O} / \mathrm{HEPES}$ & $4.70 \pm 1.97$ & $3 \pm 1$ & ND & \\
\hline $7.0^{\mathrm{d}}$ & $\mathrm{H}_{2} \mathrm{O} / \mathrm{HEPES}$ & $5.00 \pm 0.01$ & $4 \pm 1$ & $\mathrm{ND}$ & NA \\
\hline $8.0^{\mathrm{d}}$ & $\mathrm{H}_{2} \mathrm{O} / \mathrm{HEPES}$ & $4.58 \pm 0.01$ & $4 \pm 1$ & $\mathrm{ND}$ & $\mathrm{NA}$ \\
\hline $5.5^{\mathrm{e}}$ & $\mathrm{H}_{2} \mathrm{O} / \mathrm{MES}$ & $7.72 \pm 4.61$ & $15 \pm 2$ & $6 \pm 6$ & $\mathrm{NA}$ \\
\hline $6.5^{\mathrm{e}}$ & $\mathrm{H}_{2} \mathrm{O} / \mathrm{MES}$ & $5.61 \pm 1.03$ & $7 \pm 1$ & $\mathrm{ND}$ & NA \\
\hline $6.0^{f}$ & $\mathrm{H}_{2} \mathrm{O} / \mathrm{MES}$ & $5.68 \pm 2.84$ & $5 \pm 1$ & ND & $\mathrm{NA}$ \\
\hline
\end{tabular}

${ }^{\mathrm{a}}$ Means are reported plus/minus one standard deviation. The means are the average of three measurements on three-six samples, and the EPR samples contained $10 \mu \mathrm{M}$ DCMU, $3 \mathrm{mM}$ potassium ferricyanide, and $3 \mathrm{mM}$ potassium ferrocyanide, except where noted. ${ }^{b} \mathrm{Fast}$ phase amplitudes, fast phase rate constants, and the amplitude of the non-decaying component, obtained from a biexponential fit to the EPR kinetic data. Fits were performed with Igor Pro software (Wavemetrics, Lake Oswego, OR). The slow phase rate constants and amplitudes are presented in paper. The mean $\mathrm{chi}^{2}$ values for the fits were $2.0 \pm 0.1 \times 10^{7}$. Monoexponential functions gave a less reliable fit to the data, as assessed by the chi ${ }^{2}$ value. When the amplitude was less than or equal to $1 \%$, the amplitude is reported as not detected (ND). 'Ratio of the rate constant measured in ${ }^{1} \mathrm{H}_{2} \mathrm{O}$ to the rate constant in ${ }^{2} \mathrm{H}_{2} \mathrm{O}$. NA is not applicable. ${ }^{\mathrm{d}}$ Samples contained only $10 \mu \mathrm{M}$ DCMU, and the mean is the average of three measurements on two

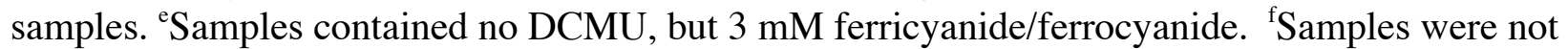
dialyzed. 
Figure $\mathrm{S} 1$. Kinetic data, associated with the reduction of $\mathrm{YD}^{\bullet}$ by $\mathrm{Q}_{\mathrm{A}}^{-}$, in ${ }^{1} \mathrm{H}_{2} \mathrm{O}$ (blue, solid lines) and ${ }^{2} \mathrm{H}_{2} \mathrm{O}$ buffers (red, solid lines). The corresponding fits (black) and residuals (dotted) are shown in A-C. The data were fit from 56 to $1128 \mathrm{~s}$. The traces shown in panels A-E were offset on the y-axis for presentation purposes. The ${ }^{1} \mathrm{H}_{2} \mathrm{O}$ and ${ }^{2} \mathrm{H}_{2} \mathrm{O}$ kinetic traces were also adjusted to give the same amplitude at $\mathrm{t}=56$ for presentation. (A) $\mathrm{pL} 8.0$ in HEPES buffer; (B) $\mathrm{pL} 6.5$ in MES buffer; (C) pL 5.5 in MES buffer; (D) pH 5.5 in MES buffer, no illumination control; (E) pL 6.5 blank in MES buffer containing DCMU, ferricyanide, and ferrocyanide, but excluding PSII. Experimental conditions: frequency, $9.8 \mathrm{GHz}$; time constant, $1.3 \mathrm{~s}$; conversion time, 164 ms; modulation amplitude, $5.0 \mathrm{G}$; modulation frequency, $100 \mathrm{kHz}$; microwave power, $6.4 \mathrm{~mW}$; concentration, 1.7-2.1 $\mathrm{mg} \mathrm{chl}(\mathrm{ml})^{-1}$.

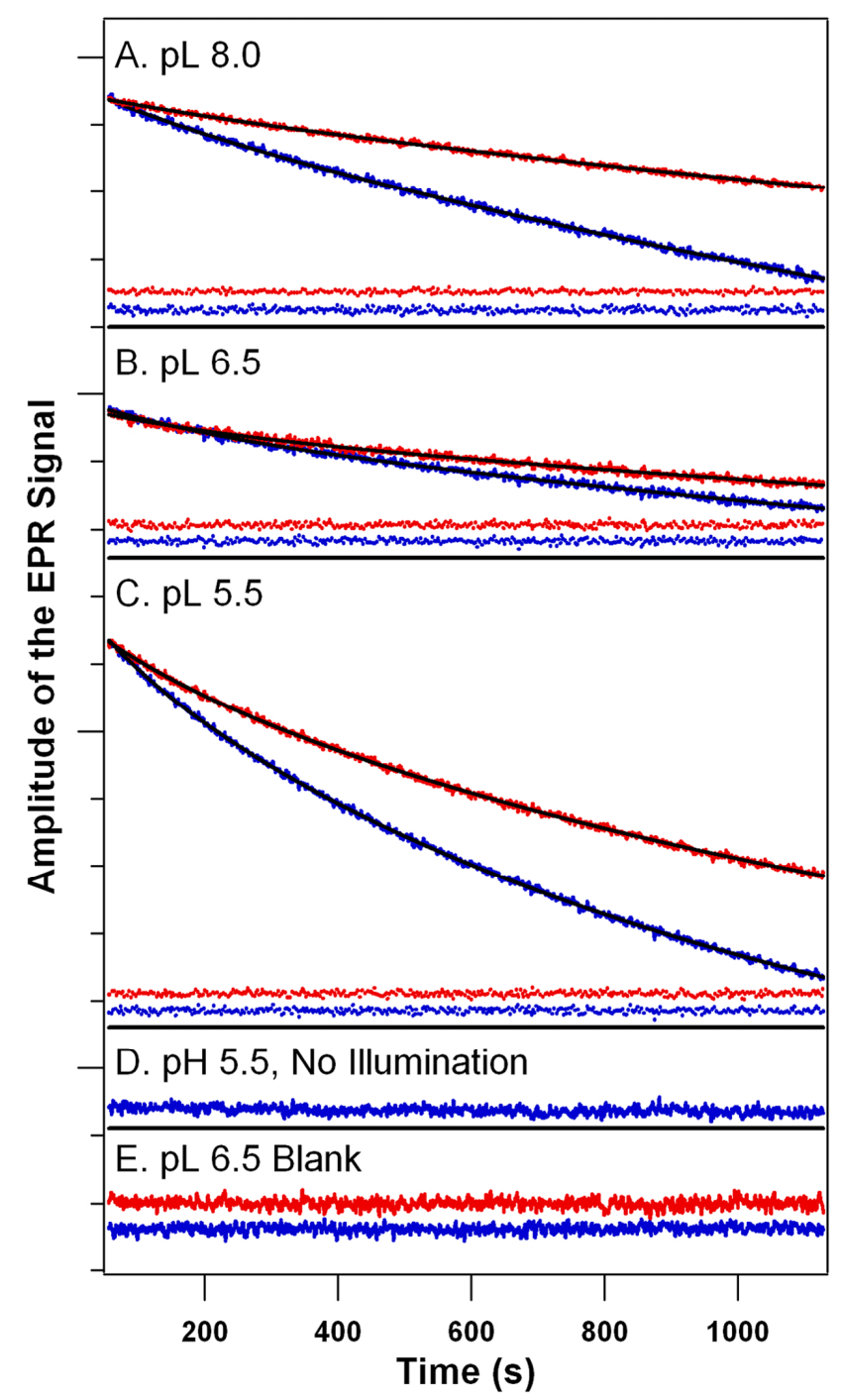


Figure S2. Representative FT-IR absorption spectra, used to quantitate the extent of deuterium exchange in PSII samples. The data are normalized to the amide I band intensity at $\sim 1650 \mathrm{~cm}^{-1}$ and were acquired at pL 6.0. The solid line is the absorption in $\mathrm{H}_{2} \mathrm{O}$. The dotted line is the absorption in ${ }^{2} \mathrm{H}_{2} \mathrm{O}$.

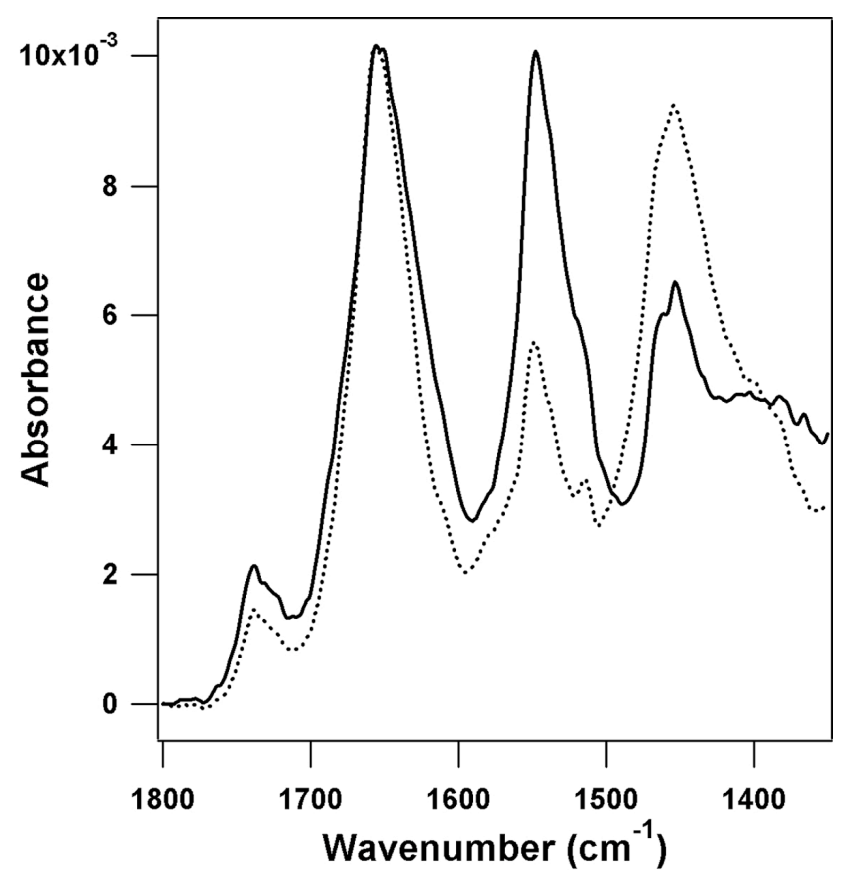

